\title{
都市計画マスタープランに見る 低炭素化のためのコンパクトシティ政策の現状
}

\author{
谷口 守 1 肥後 洋平 2 ・落合 淳太 $^{3}$ \\ 1正会員 筑波大学大学院教授 システム情報系社会工学域（テ305-8577 茨城県つくば市天王台一丁目1-1） \\ E-mail:mamoru@tsukuba.ac.jp \\ 2非会員 筑波大学大学院 システム情報工学研究科（テ305-8577茨城県つくば市天王台一丁目1-1） \\ E-mail:higo80@sk.tsukuba.ac.jp \\ 3非会員 筑波大学大学院 システム情報工学研究科（テ305-8577 茨城県つくば市天王台一丁目1-1） \\ E-mail:s1120514@sk.tsukuba.ac.jp
}

\begin{abstract}
持続可能な都市実現に向けて, 環境負荷の少ないコンパクトシティへの期待が一層高まっている．しか し，各都市がぞのようにコンパクトシティ実現のための政策を掲げているかは整理されていない．本研究 では40都市に渡る都市マスの記述を客観的に読み解き，各都市のコンパクトシティの捉え方や政策の種類， また，相反する記述など様々な面からコンパクトシティ政策の採用実態を時系列的に把握した．分析の結 果，大都市圈都市の多くが都市マスにおいてコンパクトシティ政策を多く掲げるようになったことが示さ れた。一方で，人口20万人以下の地方圈都市は，ほとんど掲げられておらず，掲げていても都市の低炭素 化を意図していないものや，郊外部の開発を容認する政策を掲げている都市も見られることが明らかにな った.
\end{abstract}

Key Words : compact city, municipal master plan, low-carbon society, $\mathrm{CO}_{2}$ emission

\section{1. はじめに}

モータリゼーションの進展に伴う自動車依存型都市の 形成により，自家用車利用頻度や走行距離が増大し，そ れに伴うエネルギー消費量の増加によって, 温暖化など の地球規模での環境問題が顕在化している.2009年時点 の日本の $\mathrm{CO}_{2}$ 排出量をみると, 運輸部門から排出される $\mathrm{CO}_{2}$ は全体の $20.1 \%$ 占めている1. 日本が国際的に公約 している2020年までにCO 2 排出量を1990年比25\%削減す るという目標2をを達成していくためには，この自動車か らの $\mathrm{CO}_{2}$ 排出量の削減が必要不可欠である.

また，わが国では2000年頃から中心市街地の活性化や 都市インフラの維持コスト低減, 交通環境負荷低減など の観点から，自動車に依存しない高密で効率的な都市構 造として, コンパクトシティが注目されることとなった. この都市のコンパクト化を通じて一定の $\mathrm{CO}_{2}$ 排出量削減 が可能であることは既に実証されている3.4.

このような流れを受けて，2007年には社会資本整備審 議会答申において「集約型都市構造」の重要性がようや く明記され5)，コンパクトシティを目指すことが政府の
方針として明確化された．国土交通省が自治体に対して 実施した簡便なアンケートによると，2010年4月時点で 1420都市のうち約半数が，都市計画マスタープラン（以 降都市マス) においてコンパクトシティや都市の集約化 を掲げているとされているす。 一方で，コンパクトシテ イといら用語を単なる特定開発事業の遂行や地方自治体 のPRなどに用い，実際はそれまでの拡散型都市づくり を継続するといった，本来の趣旨とは異なる目的でその 用語のみが濫用されるケースがあることも指摘されてい $ろ^{7}$.

各都市が真剣に都市コンパクト化を通じて低炭素化を 促進しようとしているのか，それとも単に用語としての み採用しているのか，その違いは将来に大きな違いを生 むと考えられる重要な問題である.ちなみに現在より 10 年以上前に全国の都市マスの中でコンパクトシティがど のように用語として扱われているか，実際に検討を加え た優れた研究は既に存在する ${ }^{899}$. しかし, 先述したよう な国としての方向性が示された後での各自治体の都市マ スでの内容が，以前と比較して時系列的にどのような変 遷をたどっているのかはまだ明らかにされていない，ま 
た，都市マスの中まで実際に読み込みを詳細に行い，関 連する政策メニューが実際に準備されているかどうかや, コンパクト化と相反する内容の記述が存在しないかどう かといった，マスタープランの文脈（コンテクスト）に まで立ち入った研究は大きな労力を要するため, 実際に は取り組まれていない.

そこで本研究では，都市マスに掲げるコンパクトシテ イ政策の実態について，近年に及ぶまで経年的にその記 載状況を初めてそのコンテクストまでを読み込むことを 通じて丹念に追跡する. 手法として，キーワード抽出に 基づく客観的な分析を遂行するとともに，コンパクト化 と相反する記述がないかということも含めて精查を行う。 具体的には，客観的な分析を可能にするため，独自に作 成した政策抽出マニュアルをもとに，コンパクトシティ を掲げる上での捉え方，実現に向けた政策の種類，相反 する記述の存在などの観点から都市マスの中でのコンパ クトシティ政策の実態と変遷を時系列的に把握する.さ らにその結果と都市特性との関係性を考察することを通 じ，今後都市のコンパクト化を進めていく上で，自治体 関係者や専門家が参考とし得る情報を提供する.

\section{2. 本研究の特長}

本研究の特長は下記のとおりである.

1) 個別の都市マスを細部まで読み込むことで，単なる キーワード分析ではなく，そのコンテクスト（文 脈）を配慮した分析を実施する. 特にコンパクト化 を標榜しながら，一方で都市拡大を容認するといっ た内容の相反にも初めて目を向ける.

2) 独自にコンパクトシティ政策抽出マニュアルを作成 し，客観的に政策を把握することで都市間での比較 分析を可能としている.

3) 改訂前の都市マスもすべて収集することで，一時点

表-1 分析対象 40都市一覧

\begin{tabular}{|c|llll|}
\hline 都市の位置分類 & \multicolumn{4}{|c|}{ 都市 } \\
\hline 大都市圏 & 札幌市 & 仙台市 & 壬葉市 & 横浜市 \\
核都市*1 & 川崎市 & 名古屋市 & 京都市 & 大阪市 \\
\hline & 神戸市 & 広島市 & 福岡市 & 北九州市 \\
\hline 大都市圈 & 塩金市 & 所沢市 & 松戸市 & 春日井市 \\
周辺都市*2 & 宇治市 & 堁市 & 奈良市 & 吳市 \\
\hline & 弘前市 & 湯沢市 & 盛岡市 & 郡山市 \\
& 宇都宮市 & 上越市 & 金沢市 & 山梨市 \\
地方圏都市*3 & 静岡市 & 岐阜市 & 松江市 & 安来市 \\
& 海南市 & 徳島市 & 今治市 & 高知市 \\
& 南国市 & 熊本市 & 人吉市 & 鹿児島市 \\
\hline
\end{tabular}

*1大都市圈核都市: 五大都市圏の中心都市と人口 100 万規模の都市 *2大都市圈周辺都市 : 大都市圈内に位置するその他周辺都市 *3地方圏都市: 大都市圏以外に位置する都市
のみならず，時系列的，かつ網羅的な分析を実施し た.

\section{3. 分析対象都市}

我が国のコンパクトシティ政策について幅広く実態を 把握するため, 規模や特性の異なる様々な都市を対象と する必要がある。そこで本研究では，全国都市交通特性 調査において, 継続して調査対象とされている 40 都市 を取り上げることとした（表-1） ${ }^{10)}$ 。この全国都市交通 特性調査は，都市の基礎的な交通特性を把握するととも に，全国の横断的，時系列的な比較分析を行う目的で実 施されている. そのため, 対象都市は1)都市の人口規模, 2)都市圈の規模（大都市圈，地方都市圈など），3)都市 圈内での位置（核都市，周辺都市）などの性格が異なる 都市をバランスよくカバーするように選定されており， 都市マスについて横断的で時系列的な分析を行う本研究 において，この 40 都市を選定することが最も適切であ ると判断した. 以下では全国都市交通特性調査の分類を もとに，対象都市を表-1 のように大都市圈核都市（太 字・下線），大都市圈周辺都市 (太字・斜体)，地方 圈都市 (標準) の3つに分類した（括弧内は図表内での 各都市分類の表示方法).

分析対象期間は，対象都市が策定したすべての都市マ スを網羅できるよう， 1994 年から 2011 年とした. この 期間都市マスを全面的に改訂したのは 11 都市で，その 改訂前のものも含め, 全 51 冊, トータルのページ数と しておよそ 8,000 頁にわたる都市マスの記述を分析対象 とした.

\section{4. コンパクトシティの捉え方の変遷}

\section{(1) 分析の方法}

まずはじめに，都市マスにおいて，いずれの都市が コンパクトシティを理念としてその内容に掲げている のかを明らかにする，具体的には，都市マスの将来都 市像に「コンパクトシティ」，「都市のコンパクト 化」，「集約化」を明示的に掲げているかを把握する。 本研究ではこれらの用語のいずれかを掲げていれば,

「コンパクトシティ」を政策として掲げていると判断 する. なお，この部分の分析方法は通常のキーワード 分析と変わるところはないが, これは各都市の都市マ スの冊子をべースに文章を読み取ることで分析を行っ ており, 電子データ上でのキーワード検索機能等は使 用したものではない. 
次に，各都市マスを更に読み込むことで，コンパクト シティを掲げているかどうかとは無関係に，その理念に 低炭素化の意図が含まれているかどうかを判読した。 た だし，1章でも述べたように，コンパクトシティとは単 に低炭素化を実現するためだけの都市構造ではない，そ こで, 次にコンパクトシティを掲げている都市について, 低炭素化の目的で掲げているのか，または，低炭素化を 含む複数の目的で掲げているのか，それとも低炭素化以 外の目的で掲げているのかを吟味する. 低炭素化以外の 具体的な目的としては，コンパクト化に対して継続的に 検討を行っている社会資本整備審議会都市計画制度小委 員会の資料 ${ }^{11)}$ 参考に，「暮らしやすさ・活力」「都市 経営」「自然的環境の保全」の3つの範疇を設定した.

このうち，「暮らしやすさ・活力」は，人や都市機能 を集積することでまちの賑わいを高め, 暮らしやすさを 改善することを通じて今後の人口減少社会, 少子高齢化 社会に対応していこうとするものである.「都市経営」 は，市街地の外延化を防ぐことなどでインフラの整備維 持費を削減し，経営面から持続可能な都市を形成しょう とするものである. 最後に「自然的環境の保全」は，都 市の低炭素化を意図しているものではなく, 都市のコン パクト化を通じて市街地の外延化を防ぎ周辺の森林や農 地など自然的な環境を保全しようとするものである.

なお，都市マスの改訂を行っている都市に対しては， 改訂に際してどのように方針を転換しているのかという 変化の中身についても分析を行った.

\section{(2) 変遷の実態}

18年間にわたる連続的な分析結果から，ここでは変化 の動向を端的に考察できる3時点の結果のみを抽出し, 図-1に示す．この図から以下の事項が考察できる.

1)（その1）2001年時点で都市マス策定済みで，かつ コンパクトシティを掲げている都市は仙台，松戸， 呉の3都市のみであり，そのうち低炭素化を目的と しているのは仙台と松戸のみである. 他の19都市で は都市マスを策定しているが，コンパクトシティの 考えは導入されていない.この他の18都市では都市 マス自体がまだ策定されていない.

2）社会資本整備審議会答申直前の（その2）2006年時 点を見ると, コンパクトシティを掲げる都市が11都 市に増えたことがわかる．都市マス自体を策定して いない都市はこの段階で5都市に減り，5年の間に13 都市が新たに都市マスを策定している．その13都市 のうち，8都市にコンパクトシティの考えが導入さ れ，うち大阪や札幌などの5都市が低炭素化を実際 に目的としている.

3) 最近の（その3）2011年時点では, 全体の過半数と なる22都市でコンパクトシティが掲げられるように

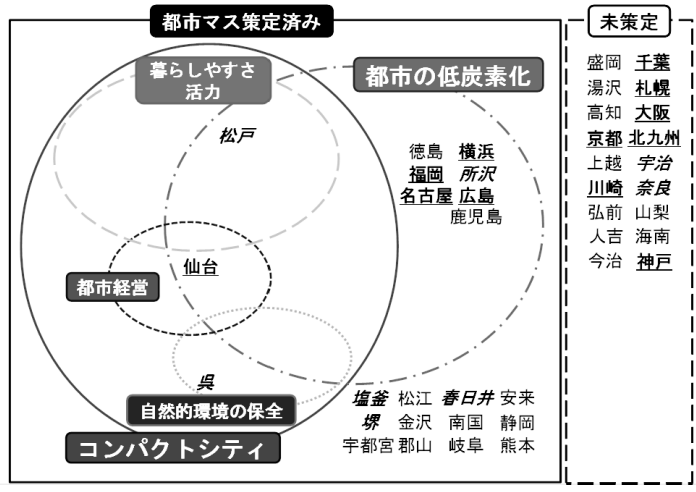

（その 1）2001年時点

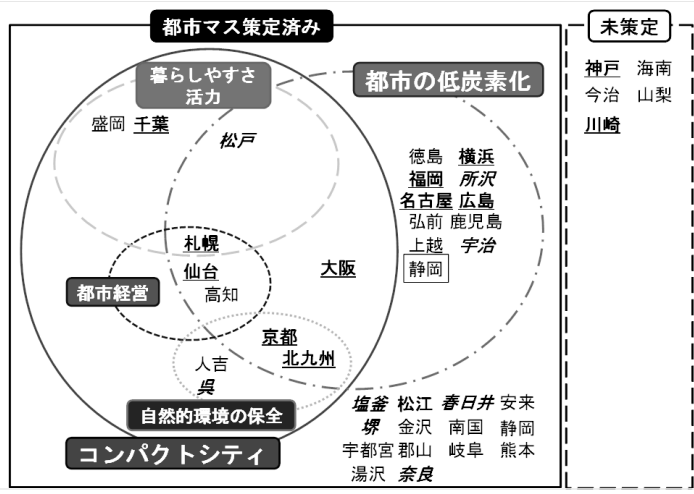

(その 2) 2006年時点

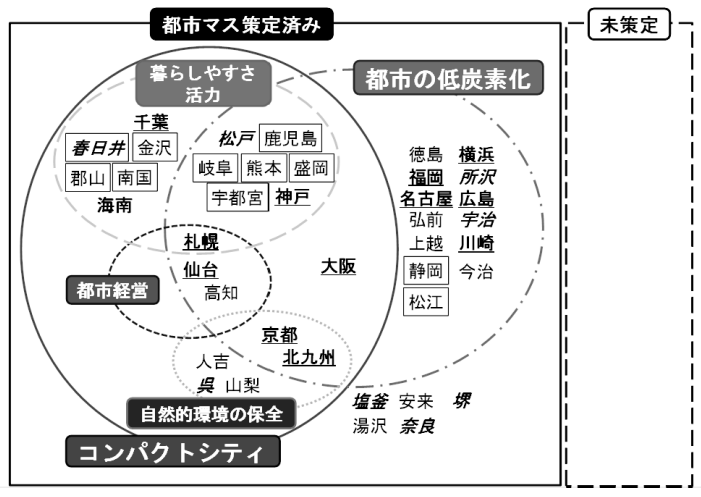

(その3) 2011年時点

都市名 : 改訂後の現行の都市マス

図-1 都市計画マスタープランの将来都市像における

コンパクトシティの採用実態とその目的の変遷

(2001年, 2006年, 2011年時点)

なっている．この割合は先述した国土交通省の調查 とも合致しておりの，その内容を裏付けるものであ る.しかし，その一方で都市マスの内容まで読み込 むと，実際に低炭素化を政策として念頭に置いてい る都市は神戸など13都市にとどまり，全体の40都市 の中ではまだ3割に満たない。一方で都市コンパク 卜化を掲げることなく，低炭素化を都市マスの目的 
に含む徳島などの都市も13存在する.

4）（その2）2006年時点と（その3）2011年時点を比較 すると，この期間中に都市マスを改訂した都市のほ とんど（10都市中9都市）が，新たにコンパクト化 政策を掲げるようになっている.また，それらの多 くは鹿児島や熊本，盛岡などの地方圈都市である.

5）（その3）2011年時点になると, 都市マス未策定の 都市は無くなっている. 都市マスを策定していても， コンパクトシティと低炭素化のいずれをも目的とし ない都市も5つのみ（湯沢, 塩釜, 安来, 堺, 奈良) と（その2）2006年時点と比較すると大きく減少し ている.

なお，本分析では，今回設定した「暮らしやすさ・活 力」「都市経営」「自然的環境の保全」の3つの範疇を 複数満たす都市は，「暮らしやすさ・活力」と「都市経 営」について言及していた札幌市のみであった.

\section{5. コンパクトシティ政策の種類からみた現状}

\section{(1) 政策抽出マニュアルの作成}

各都市の定める都市マスは, その構成や内容, 記述の 仕方などが様々であり，そのままでは客観性のある定量 的な分析に供することができない. 本研究では都市マス におけるコンパクトシティ政策の記述を同一のルールで 分析するため, 独自に政策抽出マニュアルを作成した. マニュアルについてはコンパクトシティ政策の内容や多 様性を正確に反映するため, 既存のガイドラインや関連 する解説書に基づいてその内容を構築した．具体的には
国土交通省が刊行した『低炭素型都市づくりガイド

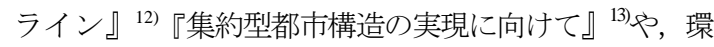
境省が刊行した『低炭素社会づくりに向けて』14)『低炭 素型都市構造を目指した都市づくりの推進』 ${ }^{15}$ の記述内 容を網羅的に吟味することで，コンパクトシティ政策を 示すキーワードを網羅的に計89個設定した. これら89個 のキーワードはその政策分野の類似性から表-2に示した 全12個の分野メニューを構成している. 各分野メニュー とキーワードについては表-2の通りである.

分析の際は都市マスの基本的な章構成にも配慮してい る. 基本的な構成として，まず将来都市構造を提示する 章があり, 次に, その都市構造を実現するための土地利 用など各分野の具体的な政策を示寸章がある.このこと を考慮し, 将来都市構造について提示している章につい ては都市構造分野メニューが，各分野の分野別構想など 具体的な政策を提示している章については，土地利用， 交通，エネルギーのそれぞれの分野の各メニューが対応 している. このようにマニュアルにおいて分野やキーワ 一ドを定義し，その89固のキーワードについて，都市マ スの中で記載の有無を把握した。ここまでは通常のキー ワード分析であるが，さらに，キーワードの記載があれ ば表-2の詳細に定めたルールに従って, その前後の詳し いコンテクストを読み解き, 低炭素化の意図をもって政 策として掲げられていると判断できる場合に，その政策 の分野メニューが掲げられているとした，例えば「環境 負荷低減のためにTDMを実施していく」という記述が ある場合は交通分野のTDMという政策メニューが掲げ られていると判断した.

このような方法を採用したのは，「コンパクト」とい

表-2 低炭素化を意図したコンパクトシティ政策の分野メニューとキーワード例

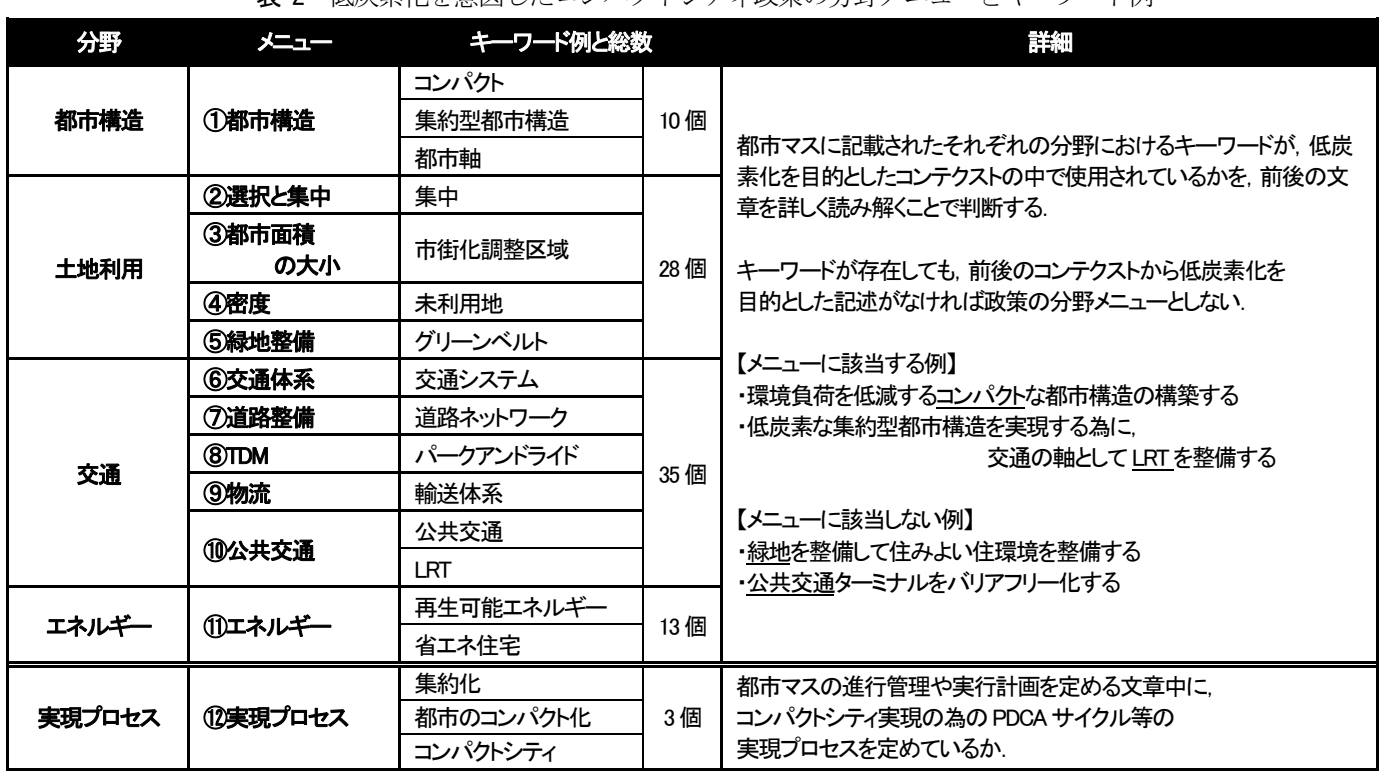


うキーワードを文章中に持たなくとも，コンパクト化の ための政策メニューは多く存在するからである．たとえ ば，「公共交通の利便性の高いエリアにおいて居住を促 進していく」といった政策は立派なコンパクト化政策と いえるが，その中には「コンパクト」という用語はなく， ここで取り上げた政策キーワード群を通じて別途丹念に 拾う必要がある．また，公共交通に関連するキーワード として拾われても，「公共交通ターミナルをバリアフリ 一化する」といった記述であれば，低炭素化を意図に含 む政策とは判断できない．本分析ではこのようにコンパ クト化に関連する可能性のある政策キーワードをまず広 く客観的にすべて拾い上げ，なおかつ同じキーワードで あっても，それが低炭素化を目的としたコンテクストの 中で使用されているかどうかを一つ一つ丁寧に判読した.

また，都市マスに掲げられたコンパクトシテイ政策を 確実に実現していくため, 分野メニュー12)を設定した.

これは政策の分野メニュー(1)から(111について，その後ど のようにその政策を実現していくかという計画（実現化 のためのプロセス）も，コンパクトシティを実現してい くための政策のひとつであると考えたためである.メニ ュー12については, コンパクトシティ実現の理念のもと にプロセスを定めているかを判断するために，都市マス における進行管理や実行計画について定めている文章を 対象とする. そして，4章で用いた「コンパクトシテ イ」,「都市のコンパクト化」，「集約化」というキー
ワードを用いてPDCAサイクルを確立するといった実現 プロセスを掲げている場合のみメニューに該当するとし た. 以上のプロセスを適用することにより，その都市マ スがどの分野メニューにおいて低炭素化を意図してコン パクトシティ政策を構築しているかを正確に解読した.

同時に，本分析では都市マス内の記述をすべて精査し， コンパクトシティ実現のための政策と相反する記述もす ベて抽出した.

\section{(2) 抽出結果}

分析の結果を図一2に示す．この図は，都市が都市マ スに掲げている低炭素化を意図したコンパクトシティ政 策の分野メニューの種類（全12種類）と，都市マスの策 定・改訂年次との関係を, 都市の分類とともに示したも のである.この図より, 以下の事項が考察できる.

1) 全体的に右肩上がりの傾向を示してきていることか ら，策定年次の新しい都市マスほど，低炭素化を意 図したコンパクトシティ政策の分野メニューが多く 掲げられていることがわかる．2007年の社会資本整 備審議会答申以降に着目寸ると, 都市マスを改訂し た10都市のうち8都市が, 改訂前に比べ, 分野メ二 ューを増やしており, 改訂の機会をうまく活かして いることが読み取れる.

2) 人口規模の大きな都市ほど分野メニューを多く準備 寸る傾向にある. 必要とされる政策の多さ，またそ

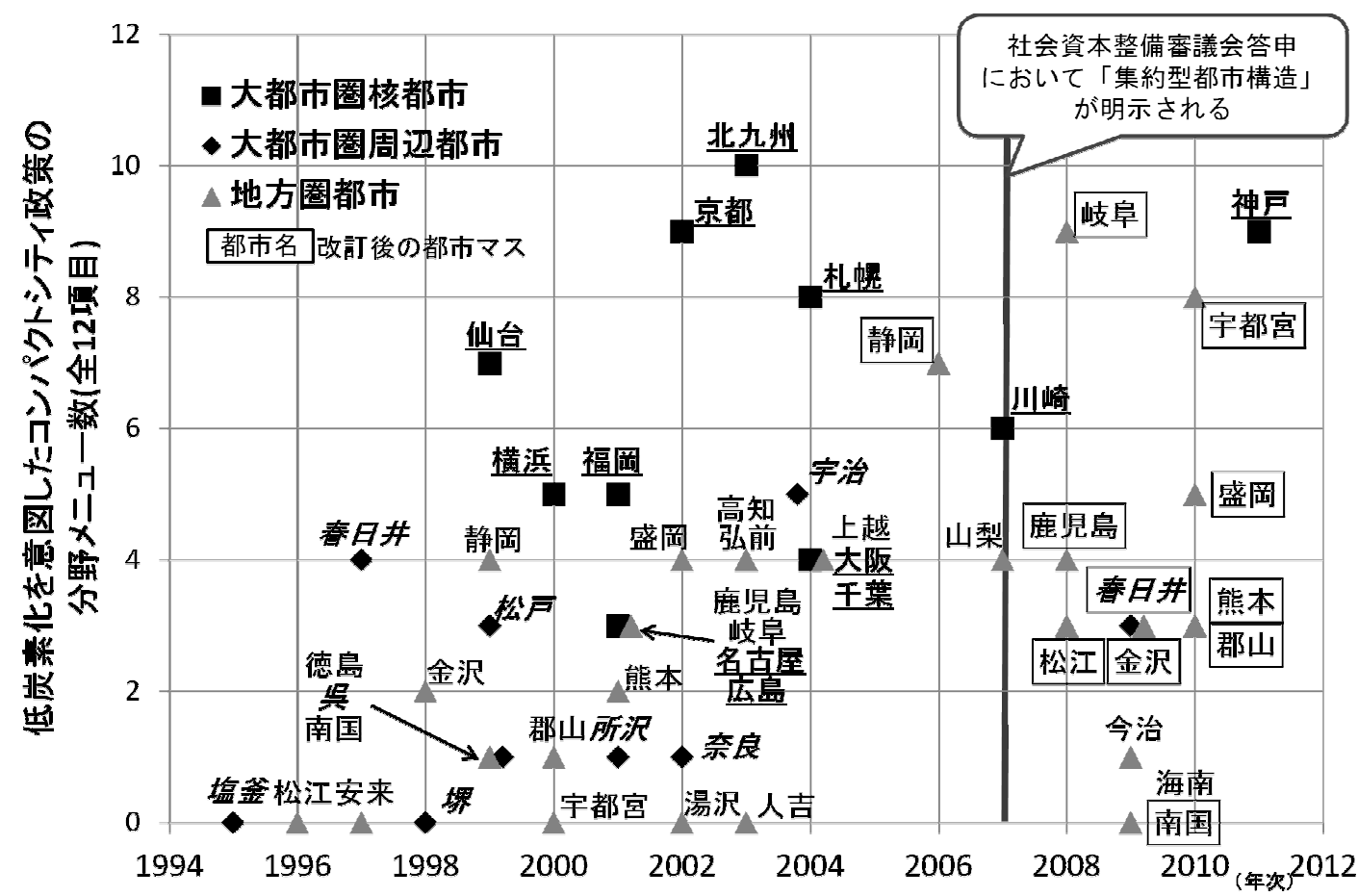

図-2 各都市計画マスタープランにおける低炭素化を意図したコンパクトシティ政策の分野メニュー数 
れに対する対応能力から考えて，これは当然の結果 といえる．特に仙台や北九州，京都などでは2007年 の社会資本整備審議会答申より以前から多くの分野 メニューを掲げている.

3) 社会資本整備審議会答申以降の地方圈都市のみに着 目すると，宇都宮や岐阜など，人口が40万人を超す ような，比較的人口規模の大きな都市において，分 野メニューが多く掲げられていることがわかった。

一方で，海南や人吉，今治など人口が20万人に満た ないような比較的小規模な都市では，ほとんど分野 メニューが見られず，策定時期が同じでも，都市の 人口規模により，コンパクトシティ政策の導入状況 に差があることが明らかになった.

4) 静岡や川崎などは，4章において都市マスの将来都 市像にコンパクトシティ掲げていないとされた都市 である.しかし分析の結果, 川崎は6種類, 静岡も 改訂後は8種類もの分野メニューを記載しているこ とがわかり，都市マスにコンパクトシティを掲げて いなくても実質的な低炭素化政策を既に掲げている 都市も実は少なくないことが明らかになった.

\section{(3)コンパクトシティと相反する記述の実態}

4章で多くの都市が都市マスにコンパクトシティを掲 げるようになってきていることが明らかになった，しか し，1章でも述べたように，コンパクトシティという用 語のみが濫用されていて, 都市のコンパクト化と矛盾し た，都市の拡大を許す方針が立てられている可能性もあ る.

そこで，都市マスにおいて都市のコンパクト化と相反
する記述を詳細に読み込んだ。すべての都市マスの記述 について検討を行ったが，ここではその中でも重要性の 高い都市構造全般と市街化調整区域の開発に関連した部 分に絞って，分析結果を提示する.

まず都市構造全般と市街化調整区域における，都市の 拡大を伴うような拡散型開発を容認している記述のあっ た都市とその記述の一覧を表-3（その1）に示す。上越 では将来の都市圈人口増加を想定した都市基盤の拡大に 言及している４4章の結果と照らし合わせると，上越， 安来，奈良はコンパクトシティを掲げておらず，依然都 市の拡大を容認する傾向にある．鹿児島は2008年に都市 マスを改訂した際, 将来都市像に低炭素化を意図したコ ンパクトシティを掲げるようになっていたが，市街化調 整区域における宅地開発を容認している記述が見受けら れ，拡大を抑えるべき地域に対し適切な方針転換が十分 示されているとは考えにくい.

また，これらのように明確に相反が読み取れなくとも， 相反を容認し得る内容と思われる記述も少なくない，具 体的には，開発許可制度や土地区画整理事業によっての み開発を許可するといった具体的な整備方針が書かれて いる都市でも，具体的な整備方針の記述がなく，「周辺 環境と調和した」「既存住宅地に配慮した」といった如 何様にも取れる記述がされているものは要注意といえる. これらを「弱い」相反性と判断し，そのような記述の見 られた都市を表-3 (その2) に示す.これらの都市は, 積極的な都市の拡大は行わないとしながらも，その中身 において，十分にその可能性を排除したとは言い切れな い.

なお，以上の諸都市において，そもそも安来，奈良，

表-3 都市計画マスタープランにおいてコンパクトシティと相反する記述が見られた都市と記述

（その1）市街化調整区域の開発を容認している記述などがみられた 4都市とその内容

\begin{tabular}{|c|c|c|}
\hline 都市 & 策定年次 & 市街化区域拡大や市街化調整区域に関する方針 \\
\hline 安来 & 1997 & (市街化調整区域) IC 周辺に便利で豊かな住宅地の形成を図る \\
\hline 奈良 & 2002 & (都市全体)線状都心構造から面的都心構造への拡充 \\
\hline \multirow{2}{*}{ 上越 } & \multirow{2}{*}{2004} & 将来の人口増加の受け皿整備, 人口定住化のための適切な市街地確保 \\
\hline & & 30 万人都市機能整備に向けての初期段階としての土地利用推進 \\
\hline \multirow[b]{2}{*}{ 鹿児島 } & \multirow[b]{2}{*}{2008} & (市街化調整区域)田園風景と調和した市営住宅建設の推進 \\
\hline & & $\begin{aligned} \text { (保留人ロフレーム予定地・部市街化調整区域)地区計画により } \\
\text { ゆとりのある良好な宅地開発を誘導 }\end{aligned}$ \\
\hline
\end{tabular}

（その 2）拡散型の開発を容認し得る記述がみられた5都市とその内容

\begin{tabular}{|c|c|c|}
\hline 都市 & 策定年次 & 市街化区域拡大や市街化調整区域に関する方針 \\
\hline 堺 & 1998 & $\begin{array}{r}\text { (市街化調整区域)都市基盤の整備の状況により， これらを有効利用しつつ, } \\
\text { 都市的土地利用の計画的な誘導をめざす }\end{array}$ \\
\hline 名古屋 & 2001 & $\begin{array}{l}\text { (市街化調整区域)新たに市街地整備を行う地区では, } \\
\text { 自然環境や農地などと調和したゆとりあるまちの形成に努める }\end{array}$ \\
\hline 京都 & 2002 & (市街化区域)環境を勘案して必要最低限の範囲で市街化区域拡大を検討する \\
\hline 南国 & 2009 & (市街化調整区域)周辺環境への影響に十分配慮したうえで新たな工業系市街地を形成 \\
\hline 今治 & 2009 & （農地・集落地）新規住宅の供給にも配慮するが，周辺環境や集落地との一体性確保 \\
\hline
\end{tabular}


堺などは図ー1に示したとおり理念としてもコンパクト シティを掲げているわけではない.このため, 上記す心゙ てが内容に相反する要素であるとは論理的には言い切れ ない点にも注意が必要である. しかし，それは相反して いないからよいといら事ではなく，まだ相反する段階に も至っていない都市も少なくないと解釈すべきである.

\section{6. まとめ}

都市マスの記述に対し客観的分析を可能にする政策 抽出マニュアルの作成・適用を通じ，一冊一冊のコンテ クストまで丹念に内容を読み込むことで，経年的分析を 行った結果, 以下のような研究成果が得られた.

1) 2007年の社会資本整備審議会答申以降，コンパク トシティを標榜する都市は加速度的に多くなって いる。しかし，それらがすべて低炭素化を念頭に おいているかといえば，そうではないことが明ら かになった。

2) 40万人を越えるような人口規模の大きい都市は 様々な政策メニューを通じてコンパクト化を実現 しようとしているのに対し，人口規模の小さな地 方圈都市は多様なコンパクト化政策を打ち出せて いないのが実情である.

3) コンパクトシティによる低炭素化を基本理念とし て定めているわけではないのに，実際にはコンパ クト化を通じた低炭素化に貢献し得る政策を無意 識に提供している都市も少なからず存在した.

4) 複数の都市においてコンパクトシティ政策を必ず しも援護しない，相反した政策が記載されている ケースがあることも明らかになった。

今後の課題として，因果関係を解明するのは容易では ないが，都市マスでの低炭素化に関する記述が，各都市 での実際の低炭素化の状況にどのような影響を及ぼして いるのか, 実際の $\mathrm{CO}_{2}$ 排出量推計などを通じて類推を行 っていく必要がある。また，都市マスで書きっぱなしと いうことではなく，実体としてどのような都市構造を達 成しているのかという「確認」行為を専門家を交えて実 施する「都市構造確認制度」といった制度の創出も有効 であると考えられる.さらに，人口規模の小さい地方都 市でも取り組めるメニューの考案や提供を行っていく必 要もある. 低炭素まちづくり法の施行などに伴い，今後 は先行する他都市のマスタープランを参照・模倣した, 補助金目当ての「思考停止」型コンパクトシティ志向都 市も増えないとは限らない. 本研究をさらに拡充してい くことで，専門家が十分な知見を持って都市構造評価に
臨めるようになることが期待できる.

\section{謝辞}

本研究の実施においては, 日本学術振興会科学研究費 補助金（基盤研究B）「エクメーネ・リサージェンスの 新体系構築」（課題番号：22360202）を得た. 記して謝 意を申し上げたい.

\section{参考文献}

1) 国土交通省 $\mathrm{HP}$ ：「運輸部門における $\mathrm{CO}_{2}$ 排出量」, http:/www.mlit.go.jp/sogoseisaku/environment/sosei_environment_tk_ 000007.html，最終閲覧 2011.12.

2) 環境省 HP : 「地球温暖化対策基本法案の閣議決定につい て」，http:/www.env.go.jp/press/press.php?serial =12257，最終閲 覧 2012.2 .

3) 森本章倫・古池弘隆：都市構造が運輸エネルギーに 及ぼす影響に関する研究, 都市計画論文集 No.30, pp.685-690, 1995.

4) 谷口守・村川威臣・森田哲夫 : 個人行動データを用 いた都市特性と自動車利用量の関連分析，都市計画 論文集 No.34，pp.967-972，1999.

5）社会資本整備審議会答申：新しい時代の都市計画は いかにあるべきか. (第二次答申) 2007.7.

6) 交通の諸問題に関寸る検討会 : 第 4 回交通の諸問題 に関する検討会, まちづくりの観点, http://www.mlit.go.jp/sogoseisaku/transport/sosei_transport_tk_000027.html，最終閲覧 2011.12.

7) 谷口守：コンパクトシティ論（近畿都市学会編） 21 世紀の都市像，一地域を活かすまちづくり一，古今 書院, 2008.

8) 神谷和彦・中村隆司：都市のマスタープランにおけ る都市将来像としてのコンパクトシティ，土木計画 学研究・講演集 Vol.25, No.113, 2002.

9) 飯田直彦：環境配慮からみた都市計画マスタープラ ンの特徵, 環境科学会誌 15(3), pp.215-220, 2002.

10）全国都市交通特性調查 HP: http://www.mlit.go.jp /crd/tosiko/zpt/index.html，最終閲覧 2012.2.

11）国土交通省 HP, 社会資本整備審議会, 都市計画制度 小委員会：「エコ・コンパクトシティの概要」, http://www.mlitgo.jp/policy/shingikai/city07_sg_000002.html，最終 閲覧 2012.2.

12) 国土交通省，都市・地域整備局：「低炭素型都市づ くりガイドライン」, 2010.

13）国土交通省，都市・地域整備局：「集約型都市構造の実 現に向けて，一都市交通政策と市街地整備施策の戦略的 展開一」, 2007.

14）環境省, 中央環境審議会地球環境部会 : 低炭素社会づく りに向けて一ライフスタイル・社会資本・環境エネルギ 一技術のイノベーション一, 2008.

15）環境省 HP：「低炭素型都市構造を目指した都市づくりの 推進」, http:/www.env.go.jp/ earth/ondanka/sakutei_manual/kaitei_ comm/com03/mat06_3.pdf, 最終閲覧 2012.1.

(2012.8. 9 受付) 


\section{CURRENT STATUS AND ISSUES OF COMPACT CITY POLICY FOR LOW CARBONIZATION FOUND IN MUNICIPAL MASTER PLANS}

\section{Mamoru TANIGUCHI, Yohei HIGO and Junta OCHIAI}

With the goal of realizing sustainable cities, expectations of compact cities that have less impact on the environment has been growing increasingly. However, policies of each city for realizing a compact city have not been established yet. Therefore, statements related to municipal master plans found in 40 different cities were examined objectively in this study. Consequently, the current status of the introduction of the compact city policies was revealed chronologically from various perspectives such as the concept for the compact city, type of policy, and allowance of retrogression. Results of examinations confirmed that many metropolitan areas have introduced compact city policies in their municipal master plans, although most suburban cities with populations of less than 200,000 have not. Moreover, although some suburban cities have such plans, they do not incorporate consideration of the low carbon usage of the city and often allow development of rural areas. 